\title{
The Local Economy and Rural Development in Berambai Hamlet, East Kalimantan
}

\author{
Arman 1,* (D) and Asep Saefuddin 2 (D) \\ ${ }^{1}$ Department of Agribusiness, Faculty of Bioindustry, \\ Universitas Trilogi, 12760, Jakarta, Indonesia \\ 2 Department of Statistics and Data Science, Faculty of Math and Science, \\ IPB University, 16680, Bogor, West Java, Indonesia \\ * Corresponding Author: arman@universitas-trilogi.ac.id
}

\section{ARTICLE INFO}

Publication Info:

Research Article

How to cite:

Arman, A., E Saefuddin, A.

(2020). The Local Economy and

Rural Development in Berambai

Hamlet, East Kalimantan. Society,

8(2), 506-516.

DOI: $10.33019 /$ society.v8i2.202

Copyright (C) 2020. Owned by Author(s), published by Society

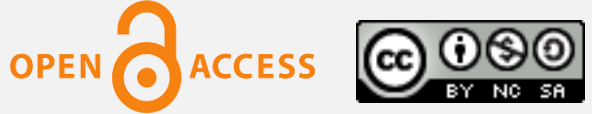

This is an open-access article.

\section{License: Attribution- \\ NonCommercial-ShareAlike (CC BY-NC-SA)}

Received: June 26, 2020;

Accepted: October 27, 2020;

Published: December 10, 2020;

\begin{abstract}
The role of the local economy gets eroded due to the inclusion of capitalization in rural areas. This research examines the coal mining industry's influence on the local economy's existence in Berambai Hamlet, Bukit Pariaman Village, Tenggarong Seberang Sub-district, Kutai Kartanegara Regency, East Kalimantan Province, Indonesia. This research uses qualitative research methods; meanwhile, data collection methods use field observation and in-depth interviews. Interviews were conducted in stages through a snowball sampling to strengthen the observations' results. The results show that the local economy and livelihood in Berambai Hamlet are under pressure and eroded due to coal mining activities. Livelihood products shrank drastically, especially fish and rice, due to mining waste polluting rivers and agricultural land conversion to mining areas. Furthermore, other sources of income from farmworkers are not enough to fulfill the needs. The government needs to protect their livelihoods as a driving force for the local economy by integrating nature-based life. The government needs to develop local economic potentials, such as tourism areas, crafts, and artworks. The government also needs to strengthen village institutions. It must be carried out together with mining companies seriously. Furthermore, the government needs to maintain the unity of rural spatial and spatial planning.
\end{abstract}

\section{Keywords: Environment; Livelihood; Local Economy; Mining Area; Rural Development}




\section{Introduction}

The activity of the coal mines mostly influences east Kalimantan's economy. The mining sector's output from 2011 to 2014 exceeded half of the other sectors' contribution, namely 56.69\%, 57.11\%, 55.21\%, and 50.11\% (Badan Pusat Statistik Provinsi Kalimantan Timur, 2016). It showed how dependent the economy of the region to the mining sector, mainly coal.

A small number of people feel the economic benefit from mining for themselves and their surroundings. Their income as mining workers doubled. They get health insurance and other luxurious facilities from the company, which almost any other companies could not give. At the same time, the government sees this as an opportunity to increase local revenue, employment, and community income.

However, coal mining companies only boost macroeconomic performance but have not yet reached significantly at the community level. East Kalimantan's Gini Ratio Index in 2011-2014 has increased from 0.32 to 0.36 (Badan Pusat Statistik Provinsi Kalimantan Timur, 2014). The index value increase indicates that economic performance is experiencing a trade-off with people's income. Mining sector activities boost regional performance but are not strongly correlated with income distribution.

Moreover, the mining sector has many "bad records" regarding environmental degradation, depletion of community livelihoods, the fragility of culture and social value systems, and the reduction of mutual trust between peoples. The main problem is conflict and weakness of social ties. This situation makes the community alienates from cultural values due to social estrangement. It reflects and happens in Berambai Hamlet, Bukit Pariaman Village, Tenggarong Seberang Sub-district, Kutai Kartanegara Regency, especially in Dayak Kenyah Lepoq tribe.

The total population of Tenggarong Seberang Sub-district, according to the 2010 population census, was 61,144 people, spread over 18 villages (Badan Pusat Statistik Kabupaten Kutai Karta Negara, 2014). Seventeen mining companies have mining business licenses for production operations, and seven companies have mining business licenses for exploration. The area controlled by mining companies with IUP production operations is 21,862.15 hectares (equivalent to $47.1 \%$ ) of the total area of Tenggarong Seberang Sub-district (Gandi \& Sunito, 2015). Land controlled by mining companies has converted the Dayak Kenyah community's agricultural land, affecting their livelihood system, which relies on shifting agriculture (Maunati, 2003). Space for them to cultivate the land will be isolated because mining companies already control the land. The company's existence does not fully accommodate the Dayak Kenyah Lepoq Tribe's collective needs in Berambai Hamlet. A small proportion of them is manual labor in the company.

Farming communities face new problems that are not equivalent to the labor absorbed in mining activities. The company's waste disposal in the Separi River ruins the source of livelihood for the people of Barambai Hamlet, which comes from the river. Separi River is an essential source of livelihood and protein needs for the Dayak Kenyah people in Berambai Hamlet. Every day they consume fish from the river and sell some of it to the market.

The local economy, socio-culture, and strong cultural values were "damaged" due to the Separi River's pollution from corporate waste. The exploitation of natural resources in coal mining, intended initially as part of rural development, creates economic, environmental, social, and cultural problems.

Before the coal mining company entered and operated in Berambai Hamlet, Kenyah Lepoq tribe's life was stable following norms and cultural rules. Social cohesion between communities

Copyright (C 2020. Owned by Author(s), published by Society. This is an open-access article under the CC-BY-NC-SA license. https://doi.org/10.33019/society.v8i2.202 
is quite strong, especially during marriage ceremonies, other celebrations, agricultural land exploitation, house renovations, and cooperation throughout Berambai Hamlet activities.

When the coal mining companies were already operating in 2005, communities had started to feel the impact of the company's waste. Mining activities that pollute the river are slowly eroding people's livelihoods. On the other hand, mining companies' expansion of mining areas has narrowed the space for agricultural activities that threaten agriculture and fisheries of Dayak Kenyah Lepoq tribe livelihoods in Berambai Hamlet. Moreover, capitalization and massive mines exploitation eroded culture, local economy, and mutual trust elements. The government's role in protecting livelihoods, local economy, and tourism potential from mining companies' activities has not been optimal. The government needs to maintain and make the livelihood and tourism potential into new hamlets' economic values.

Furthermore, the cultural products of the Dayak Kenyah tribe experienced a decline due to changes in lifestyle as the impact of mining activities. Cultural rituals, such as marriage, planting, and other rituals, have gradually decreased, which is a new problem that the community does not realize besides mining activities disrupted their livelihoods. The existence of mining activities further alienates cultural elements and community values. The presence of mining companies impacts the source of livelihood and cultural preservation, such as cooperation and cultural rituals.

The Dayak Kenyah community has artistic and cultural potential that will be a livelihood and cultural preservation source if adequately managed. Gong, Kulintang, and Long Drums are traditional musical instruments used in the music and dances of the Dayak Kenyah community as entertainment performances for tourists (Haryanto, 2015). Pampang Cultural Village is a manifestation of Dayak Kenyah culture preservation as part of tourism development. Sampek music, the traditional Dayak Kenyah music, is a show for tourists (Hadibrata, 2016). Cultural preservation can be an alternative way to maintain culture as well as a new source of livelihood. Cultural preservation is also an effort to modernize the Dayak Kenyah tribe who reside in Berambai Hamlet.

Mining can exist in harmony and integrate with the pattern of life and culture. Furthermore, companies can help disseminate culture by introducing Dayak Kenyah culture as a tourism product. Agritourism-based village development can develop local economies and livelihood sources, as happened in South Africa that develops villages using the agritourism method. Agritourism is of particular significance for small-town economic development in the tourism space in South Africa. The policy offered is to strengthen agritourism as a driver for Local Economic Development (LED) in South Africa (Rogerson \& Rogerson, 2014).

The tourism sector has an essential role in the context of local economic development. Public institutions should be aware of an area's capacity and try to help develop that area. A local tourism policy towards sustainability is indispensable for the future development of an area (Pedrana, 2013). Further preservation of culture and the arts can strengthen local economies. The results show that the arts of Jaranan (artistic name of an area) have great appeal in the Kediri city community. Every show, many small traders who sell equipment and the increasing number of artisans living of appeal Jaranan art (Dewandaru \& Purnamaningsih, 2017).

It takes commitment from the region to build a culture and tourism sector as a driver of the local economy. The tourism sector provides added value to the culinary industry's influence, souvenirs, and handicrafts for the local economy in Batu city, East Java. The development of the community in the region was developed with the concept of community development with the

Copyright ( $(2020$. Owned by Author(s), published by Society. This is an open-access article under the CC-BY-NC-SA license. https://doi.org/10.33019/society.v8i2.202 
hope of forming a strong and independent community, the precious resources of innovation, and encourages cross-sector cooperation in building rural tourism (Aulya et al., 2016).

Furthermore, the community does not obtain joint ownership (common property right) from the government. It makes the indigenous's property rights transfer very quickly into the company property (Bromley \& Cernea, 1989). Capitalism seems to utilize an opportunist attitude to approach the government to obtain the optimum benefit to the common property without regard to Dayak Kenyah Lepoq tribe in Berambai Hamlet.

According to Hodgson (2004), a potential or reality of opportunism emerged as a source of "transaction costs" involved in monitoring and enforcing enforce. The attitude of extreme opportunism can reduce a person's commitment, fuel conflict, and reduce the sense of trust among each other, as happened in the Berambai Hamlet. Therefore, the rule's enforcement is significant among the principal-agents in determining the value of what is entitled by the principal-agents (Coase, 2013). In the research context, it is necessary to know the value of what is entitled to be accepted by the community after coal-mining companies operate.

Principal-agents sought to produce similar information exchange with the actors and occurred in the structure of social relations, which becomes the basis of social capital. According to Coleman (1988), there are at least three things that govern the structure of social relations, there are: (1) a bond, (2) mutual trust, and (3) the expectation. Furthermore, social capital will encourage exchanging relationships, cooperation, and establishing democracy at the community level (Putnam, 2001). If opportunism dominates, there will be mistrust in building relationships between companies, governments, and communities, and transaction costs are enormous. According to Bardhan (1996), the transaction fee is minimal in the countryside because of the close relationship in the population. However, transaction costs can become more prominent when mutual trust is declined (Fukuyama, 1995). Local economic cycles such as mutual aid are fragile, causing any farming activities to require a fee. Making contracts between perpetrators is essential that give mutual benefit and based on trust. Allen \& Lueck (2008) states that the transaction costs will decrease when the two actors establish a reputation and accept common law applicable to the community. Reputation often becomes the primary consideration to build cooperation (Keefer \& Knack, 2008).

\section{Research Methodology}

The research method used a qualitative approach. The data collection techniques used Rapid Rural Approach (RRA), interviews, direct observation, and interpretation. RRA is a way of retrieving data quickly using the five senses' capabilities (Chambers, 1992; Freudenberger, 1999). Interviews were conducted in stages through a snowball sampling to strengthen the observations' results (Onwuegbuzie et al., 2009). The chosen community leaders are the hamlet head, the Dayak tribe community, and key informants. Furthermore, conducting direct field observations, especially observing polluted rivers, occupied land, and preserved tributaries.

\section{Results and Discussion}

Bukit Pariaman Village consists of 5 hamlets: Sukamaju Hamlet, Sukarejo Hamlet, Sukasari Hamlet, Sukakarya Hamlet, and Berambai Hamlet. Dayak Kenyah Lepoq tribe is the dominant tribe in the village. In contrast with the other four hamlets in Bukit Pariaman Village, the dominant ethnic in Berambai Hamlet are Javanese and Kutai. There are numerous Javanese in the village due to the effect of transmigration in the 1980s.

According to Maunati (2003), the Dayak Kenyah tribe is part of Apokayan Dayak tribe families. The Dayak tribes belonging to Apokayan Dayak tribe families are Dayak Kenyah,

Copyright ( $(2020$. Owned by Author(s), published by Society. This is an open-access article under the CC-BY-NC-SA license.

https://doi.org/10.33019/society.v8i2.202

509 
Dayak Kayan, and Dayak Bahau. Apokayan Dayak tribe families have migrated to several regions around the 1970s. According to Haryanto (2015), the Dayak Kenyah tribe inhabits East Kalimantan.

Table 1. Geographical Distribution of Dayak Kenyah tribe in East Kalimantan

\begin{tabular}{|c|c|c|c|}
\hline Name of Tribe & Province & Regency & Location \\
\hline \multirow{7}{*}{ Dayak Kenyah } & \multirow{2}{*}{ North Kalimantan } & Bulungan & $\begin{array}{c}\text { Jelerai Selor Village } \\
\text { Tanjung Palas Sub-district } \\
\end{array}$ \\
\hline & & Malinau & Kayan Hulu Sub-district \\
\hline & \multirow{5}{*}{ East Kalimantan } & Mahakam Ulu & Long Bagun Sub-district \\
\hline & & Kutai Kartanegara & Tabang Sub-district \\
\hline & & East Kutai & $\begin{array}{l}\text { Muara Wahau Sub-district, } \\
\text { Muara Ancalong Sub-district, }\end{array}$ \\
\hline & & West Kutai & Long Iram Sub-district \\
\hline & & Berau & $\begin{array}{l}\text { Long Lanuk Hamlet } \\
\text { (Sambaliung Village) }\end{array}$ \\
\hline
\end{tabular}

Source: Haryanto (2015)

Agriculture and fisheries are the Dayak Kenyah Lepoq tribe's primary livelihoods, such as cultivating paddy fields, planting, fishing, and other livelihoods as a handyman for additional income. Cultivation of paddy fields uses rainfed agriculture technique where harvesting only happens one time in 1 year. On the other hand, they use irrigated agriculture techniques in four different hamlets where harvesting happens two times in 1 year. The varieties of paddy they use in Berambai Hamlet come from local varieties. The residents called the varieties are (1) Pada'i Kawan, (2) Pada'i Ubek, (3) Pada'i Bo'o, and (4) Pada'i Timur. The most favorite variety is Pada'i Bo'o.

The harvests from many local varieties are not sufficient for the needs of the farmer in 1 year. To get paddy/rice, they buy or receive assistance programs from the government through Raskin (Rice for the Poor) program. The harvests are sufficient to fulfill the production scale by making the new field, but they sold some of the harvests to meet their needs, such as education, health insurance, and other necessities.

When the harvest season finished, The Dayak Kenyah Lepoq tribe in Berambai Hamlet uses the field to grow some intercrops such as corn, banana, vegetable, and cassava or sometimes looking for fronds around the forest. Meanwhile, the need for fruits, they cultivate bananas, durian, langsat, rambutan, and mango. Most of the fruit source comes from the forest, just like durian, rambutan, and langsat.

However, their livelihoods are in danger of being lost due to the massive coal mining taking place in the hamlet. The river along their hamlet is polluted due to waste disposal by the company. The waste of coal production polluted the Separi River affects the livelihoods and subsistence of the Kenyah Lepoq tribe. The people of Berambai Hamlet can no longer use the river to meet their daily needs, such as drinking water sources, bathing, washing, latrines, and difficulty in catching fish. 
The fish market, which appears every month is no longer exists in the village. Most of the Dayak Kenyah Lepoq tribe's community no longer obtains fish as a livelihood source because of the Separi River's heavy pollution. Separi River pollution has destroyed livelihood. Coal mining companies eliminate the first local economy where the source is from nature and sustainable, fused with the culture and livelihood. As a result, mining activities fragmented most of the cultivation area/land.

Mining Company PT Mahakam Sumber Jaya has been conducting mining operations since 2006. Meanwhile, the Dayak Kenyah people from Apokayan Dayak tribe families lived in Berambai Hamlet in the 1990s. The Dayak Kenyah people live in peace. The fish in the Separi River are so abundant that the Dayak tribe people can harvest them to fulfill their food needs at any time.

For decades, their livelihood sources have been fused with nature and have been sufficient to sustain life. However, this time they still have to spend money to obtain drinking water and fish, and even rice. On the other hand, salable livelihood products, such as fish, are no longer there, so they have to find another livelihood source by becoming casual laborers or other jobs. The mining industry creates "impoverishment" because it eliminates livelihood sources and does not replace new livelihood sources. Furthermore, the mining industry led some communities in the region to have to migrate. They cannot consume the river's water and could not use it for the bath, wash, or latrines because it is polluted. Several families have left their homes and are looking for a new life even though there is compensation from the mining company. Meanwhile, several families survive because they do not yet know where they would go.

Several of them are trying to maintain the remaining resources to use as sources of income and livelihood. They use the land which is not being a mine into agricultural and cultivation land. Although they live in the "uncertainty" of their resources, they still hope that they owned resources and the common (rivers and land) will not change ownership and become coal mines. They live under pressure and uncertainty, but they remain alive based on cultural values and livelihood to fulfill their lives. They meet the livelihood pattern is local wisdom. The fulfillment necessities of life by bringing together the natural life cycle of planting, conservation of nature inherent to the values and way of production is a local economy.

They continue to cultivate the remaining resources according to the culture they have. Livelihood patterns remain fused with nature by not opposing the presence of modernization, reflected in how the Dayak tribe utmost care for Bamboo River (Lalut Bulog). They conserve watersheds by maintaining land cover. Although the Bamboo River is a tributary, it has a diversity of fish species and clear river water that can be consumed directly as drinking water because the Dayak Kenyah Lepoq Tribe protect and preserve nature by integrating livelihoods. It shows that the local economy can still exist amid threats to their capitalization. Law of thermodynamics by utilizing energy transfer law preserved and realized precisely by Dayak Kenyah Lepoq tribe through the local economy.

The process is a process of balance between nature and humans. The cycle of life goes by following natural life while it results in production and livelihoods. They treat nature by embedding culture in everyday life, reflecting that they can appreciate quality and original build a loving and co-exist with modernization.

They built villages with nature, but other people who come with large capital destroy villages and impoverish the community. They were in occupation of land to obtain the mine. The company uses money as a compensation tool, but simultaneously in land occupation, damaging the culture and livelihood patterns and making them powerless.

Copyright (C) 2020. Owned by Author(s), published by Society. This is an open-access article under the CC-BY-NC-SA license.

https://doi.org/10.33019/society.v8i2.202

511 
The village's development is not an accumulation but should place the element of cultural and human development. Capital is not progressing for the Dayak Kenyah Lepoq tribe in Berambai Hamlet, but capital and capital accumulation threaten their livelihood. Capitalization becomes a threat to the local economy's existence under threat of extinction in the Berambai Hamlet. The following is the results of the field findings from the survey:

Table 2. Field Survey Findings on Mining Exploitation Activities

\begin{tabular}{|c|c|c|c|}
\hline Activity & Effect & Impact & Solution \\
\hline \multirow{3}{*}{$\begin{array}{l}\text { Mining } \\
\text { Exploitation } \\
\text { Activities }\end{array}$} & $\begin{array}{l}\text { Separi River } \\
\text { Pollution }\end{array}$ & $\begin{array}{l}\text { Food sources are becoming } \\
\text { increasingly difficult }\end{array}$ & \multirow{3}{*}{$\begin{array}{l}\text { - The government needs to } \\
\text { protect the livelihoods of } \\
\text { Dayak Kenyah people } \\
\text { - It is necessary to integrate } \\
\text { mining activities with the } \\
\text { lives of Berambai Hamlet } \\
\text { people } \\
\text { - Build cultural elements as } \\
\text { part of tourism } \\
\text { development } \\
\text { - Rebuilding mutual trust } \\
\text { in Berambai Hamlet } \\
\text { community }\end{array}$} \\
\hline & $\begin{array}{c}\text { Agricultural } \\
\text { Land Conversion } \\
\text { into Mining } \\
\text { Areas }\end{array}$ & $\begin{array}{l}\text { Agricultural land is } \\
\text { shrinking, and the } \\
\text { income from farming is } \\
\text { decreasing } \\
\text { - Population migration }\end{array}$ & \\
\hline & $\begin{array}{l}\text { The Descent of } \\
\text { Social Bond and } \\
\text { Social Solidarity }\end{array}$ & $\begin{array}{l}\text { - } \text { Conflict and community } \\
\text { polarization } \\
\text { - Cultural rituals are } \\
\text { getting weaker } \\
\text { - } \text { The elements of art and } \\
\text { culture are fading away }\end{array}$ & \\
\hline
\end{tabular}

The mining industry "ruins local economy" and makes "permanent conflict" and mutual distrust between communities in the Dayak Kenyah Lepoq tribe. The community of Dayak Kenyah Lepoq ethnic that were once united now raises suspicion among those due to treatment "unfair" by the mining company. The company's presence does not create peace and cannot live side by side with the community. Dayak Kenyah Lepoq tribe threatened, scattered, and distanced itself from the environment in which they originated. If the entire population migrates, it will threaten the Dayak Kenyah Lepoq tribe's existence in Berambai Hamlet.

Those who survive because they hope that land use can still provide little hope for their survival. Cultural symbols that they have like a ritual and product in art and culture, and farming tools gradually toward extinction. Their resources are plots of land that could disappear instantly when the power of capital forced them to come out of the ground. The law does not protect them due to weak government oversight. The government should be able to intervene and defend the Dayak tribe not to be marginalized in their origination and growth.

The government must seek and maximize its role in protecting, empowering, and maintaining the regional economy to remain sustainable in the context of the spatial and sociocultural dimensions. However, the impressions that emerged in Dayak Kenyah Lepoq tribe communities shows that the government tends to protect corporations and large investors from coal mining companies.

The impressions are as follows: (1) compensation for damages. (2) only give priority to the employment of residents as laborers. (3) commit to the preservation of the environment. (4) give threat to the existence of the local economy. (5) latent community conflict, and (6) loss of common property resources. According to Subarudi et al. (2016), the formulations of policies to prevent conflicts in the community are (1) supervision and control and law enforcement, the 
realization of regulatory harmonization, implementation of good licensing governance, implementation of communication and coordination, and policy of using one map.

However, the community received compensation without economic empowerment and skills assistance. The money they receive is insufficient to create a new financial cycle that impacts their livelihood. On the other hand, livelihood source, such as fish, is no longer sufficient due to river pollution. Initially, meeting needs was sufficient, but mining companies' presence caused them to add to costs and expenses to earn livelihoods, especially fish and drinking water.

Dayak tribe's involvement as the company's workforce was not fully able to provide benefit for the Dayak Kenyah Lepoq tribe community. They are just placed as laborers while others are not working in the mining company. They are not working in the company and do not own the land are seeking other livelihood sources to survive. Moreover, their livelihood sources are no longer relying on the river because of massive river pollution. Dayak Kenyah Lepoq tribe's resources are degrading due to capital interest in mining. Simultaneously, the government's roles are weak in protecting the Dayak Kenyah Lepoq tribe.

Kutai Kartanegara's regency government has a vital role in resolving "critical" issues of the Dayak tribe and ensures the facilitation and regulation of the Dayak Kenyah Lepoq tribe's existence in Berambai Hamlet. The government should limit the exploration of coal mines. Furthermore, the government should ensure human development through education and health.

The government built Berambai Hamlet by integrating nature-based life, where their livelihood source is in the Separi River and integrates with the Dayak Kenyah community's culture. The government must preserve the Separi River. Among other things, the government's role is to maintain the unity of space and spatial planning. Therefore, mining companies need to protect and involve in preserving the Separi River. A mining company must unite with the community by maintaining the community's livelihood sources.

Tourism-based village development needs to reflect the authenticity and uniqueness of traditional rural areas, starting from the daily life of social culture, art customs, architecture, and the surrounding environment. Tourism-based village development allows for the development of various facilities so that tourists can interact with the community and make a positive contribution (Wahyudin, 1999).

Weak social capital encourages higher transaction costs. Some of the social capital decline implications in Berambai Hamlet are (1) a weakening of cooperation during the planting and harvesting. (2) distrust encourages increased transaction costs. (3) the shrinking of the local economy in Berambai Hamlet. Therefore, the government needs to optimize all the power through a technocratic approach to the Dayak Kenyah Lepoq community in Berambai Hamlet.

\section{Conclusion}

The local economy and livelihoods in the Berambai Hamlet under pressure and eroded by coal mining activity. Livelihood products shrank drastically, especially fish and rice, due to mining waste polluting rivers and converting agricultural land to mining areas. Furthermore, other sources of income of farmworkers are not enough to fulfill the needs. Dayak Kenyah Lepoq tribe in Berambai Hamlet threatened with disintegration from their land because most of them scattered in the migration process to survive. Only some of them remain to survive in their land to take advantage of the existing resources. The mining industry is the cause of the destruction of the local economy and creates poverty in Berambai Hamlet. Furthermore, social capital began to erode due to the waning of social relations' structure primarily associated with

Copyright ( $(2020$. Owned by Author(s), published by Society. This is an open-access article under the CC-BY-NC-SA license. https://doi.org/10.33019/society.v8i2.202 
the waning of bonds, trust, and expectations.

The government needs and must protect their livelihoods as a driving force for the local economy by integrating nature-based life (Wahyudin, 1999) by rebuilding mutual trust through group empowerment, education, health, and assistance. The government needs to develop local economic potential, such as tourism areas, crafts, artworks, and strengthening village institutions, with mining companies. Furthermore, the government needs to integrate mining activities side-by-side with mining exploitation by optimizing the community's local economy's empowerment.

\section{Acknowledgment}

The authors are grateful to express gratitude to all of those who have had the pleasure to work during this research conducted.

\section{Declaration of Conflicting Interests}

The authors have declared no potential conflicts of interest concerning the research, authorship, and/or publication of this article.

\section{References}

Allen, D. W., \& Lueck, D. (2008). Agricultural Contracts. In C. Ménard \& M. M. Shirley (Eds.), Handbook of New Institutional Economics (pp. 465-490). Berlin, Germany: Springer. https://doi.org/10.1007/978-3-540-69305-5_19

Aulya, R., Mindarti, L. I., \& Amin, F. (2016). Strengthening Local Economy Through Community-Based Tourism in Governance Perspective (Study at Sidomulyo Tourism Village, Batu City). Jurnal Ad'ministrare, 3(2), 11-30. https:/ / doi.org/10.26858/ja.v3i2.2424

Badan Pusat Statistik Kabupaten Kutai Kartanegara. (2014). Kutai Kartanegara Dalam Angka 2014. Retrieved from https:/ / kukarkab.bps.go.id/publication/2015/08/13/20e51f7aca7edc18d81291d1/kutaikartanegara-dalam-angka-2014.html

Badan Pusat Statistik Provinsi Kalimantan Timur. (2014). Koefisien Gini Kalimantan Timur menurut Kabupaten/Kota (Termasuk Kalimantan Utara), 1996-2014. Retrieved from https:/ / kaltim.bps.go.id/dynamictable/2018/01/17/96/koefisien-gini-kalimantantimur-menurut-kabupaten-kota-termasuk-kalimantan-utara-1996-2014.html

Badan Pusat Statistik Provinsi Kalimantan Timur. (2016). Laporan Perekonomian Kalimantan Timur $2015 . \quad$ Retrieved from https://kaltim.bps.go.id/publication/2016/12/01/0e89e46a6c68275532d1e0c8/laporanperekonomian-kalimantan-timur-2015.html

Bardhan, P. (1996). The Nature of Institutional Impediments to Economic Development (Working Paper No. C96-066). Center for International and Development Economics Research. Retrieved from https:/ / ageconsearch.umn.edu/record/233429/

Bromley, D. W., \& Cernea, M. M. (1989). The Management of Common Propety Natural Resources: Some Conceptual and Operational Fallacies (World Bank Discussion Papers 57). The World Bank. Retrieved from http://documents1.worldbank.org/curated/en/548811468740174575/pdf/multipage.pdf 
Chambers, R. (1992). Rural apprasial: rapid, relaxed and participatory (IDS Discussion Paper 311). Institute of Development Studies (UK). Retrieved from https://www.ids.ac.uk/download.php?file=files/Dp311.pdf

Coase, R. H. (2013). The Problem of Social Cost. The Journal of Law and Economics, 56(4), 837-877. https://doi.org/10.1086/674872

Coleman, J. S. (1988). Social Capital in the Creation of Human Capital. American Journal of Sociology, 94, S95-S120. https:/ / doi.org/10.1086/228943

Dewandaru, B., \& Purnamaningsih, N. (2017). Strategi Dalam Memajukan Industri Kreatif Dan Pengembangan Ekonomi Lokal Sebagai Daya Tarik Wisata (Studi Pada Kesenian Jaranan Di Kota Kediri). Jurnal Ekonika: Jurnal Ekonomi Universitas Kadiri, 1(2), 170-187. http:/ / ojs.unik-kediri.ac.id/index.php/ekonika/article/view/8

Freudenberger, K. (1999). Rapid Rural Appraisal (RRA) and Participatory Rural Appraisal (PRA): A Manual for CRS Field Workers and Partners. Baltimore, Maryland: Catholic Relief Services. Retrieved from https://www.crs.org/sites/default/files/tools-research/rapid-ruralappraisal-and-participatory-rural-appraisal.pdf

Fukuyama, F. (1995). Trust: The Social Virtues and The Creation of Prosperity. New York, USA: The Free press.

Gandi, R., \& Sunito, S. (2015). Industrialisasi Pertambangan dan Deagrarianisasi Masyarakat

Desa (Studi Kasus Masyarakat Desa Embalut dan Desa Bangunrejo, Kecamatan Tenggarong Seberang, Kabupaten Kutai Kartanegara, Kalimantan Timur). Sodality: Jurnal Sosiologi Pedesaan, 3(1), 50-62. https:/ / doi.org/10.22500/sodality.v3i1.9431

Hadibrata, W. (2016). Musik Sampek Sebagai Kemasan Wisata Di Desa Pampang Samarinda Kalimantan Timur (Thesis). Institut Seni Indonesia Yogyakarta. Retrieved from http:/ / digilib.isi.ac.id/1420/

Haryanto. (2015). Musik Suku Dayak: Sebuah Catatan Perjalanan Di Pedalaman Kalimantan. (M. H.

B. Raditya, Ed.). Retrieved from https:/ / core.ac.uk/reader/160643260

Hodgson, G. M. (2004). Opportunism is not the only reason why firms exist: why an explanatory emphasis on opportunism may mislead management strategy. Industrial and Corporate Change, 13(2), 401-418. https:// doi.org/10.1093/icc/dth016

Keefer, P., \& Knack, S. (2008). Social Capital, Social Norms and the New Institutional Economics. In C. Ménard \& M. M. Shirley (Eds.), Handbook of New Institutional Economics (pp. 701-725). Berlin, Germany: Springer. https://doi.org/10.1007/978-3-540-69305-5_19 Maunati, Y. (2003). Identitas Dayak. Jakarta, Indonesia: PT LKiS Pelangi Aksara.

Onwuegbuzie, A. J., Dickinson, W. B., Leech, N. L., \& Zoran, A. G. (2009). A Qualitative Framework for Collecting and Analyzing Data in Focus Group Research. International Journal of Qualitative Methods, 8(3), 1-21. https:/ / doi.org/10.1177/160940690900800301

Pedrana, M. (2013). Local economic development policies and tourism: An approach to sustainability and culture. Regional Science Inquiry Journal, 5(1), 91-99. Retrieved from http:/ / www.rsijournal.eu/ARTICLES/June_2013/RSI\%20J\%20June\%202013\%20Volume $\% 20 \mathrm{~V} \% 20 \mathrm{Number} \% 201 \% 20 \mathrm{final}-\mathrm{v} \cdot \mathrm{pdf}$

Putnam, R. (2001). Social capital: Measurement and Consequences. Canadian Journal of Policy Research, 2(1), 41-51.

Rogerson, C. M., \& Rogerson, J. M. (2014). Agritourism and local economic development in South Africa. Bulletin of Geography. Socio-Economic Series, 26(26), 93-106. https://doi.org/10.2478/bog-2014-0047

Subarudi, R., Kartodihardjo, H., Soedomo, S., \& Sapardi, H. (2016). Kebijakan Usaha Tambang Batubara di Kawasan Hutan: Studi Kasus Kalimantan Timur. Jurnal Analisis Kebijakan

Copyright (C) 2020. Owned by Author(s), published by Society. This is an open-access article under the CC-BY-NC-SA license. https://doi.org/10.33019/society.v8i2.202

515 
Kehutanan, 13(1), 53-71. Retrieved from https://ejournal.fordamof.org/latihan/index.php/JAKK/article/view/1314

Wahyudin, H. (1999). Pengembangan Obyek Wisata Pampang Kotamadya Dati II Samarinda Ungkapan Citra Ekokultural Arsitektur Lamin Landasan Konsepsual Perancangan (Thesis). Universitas Islam Indonesia. Retrieved from https://dspace.uii.ac.id/handle/123456789/19427

\section{About the Authors}

1. Arman, obtained his Doctoral degree from IPB University, Indonesia, in 2016. The author is an Assistant Professor at the Department of Agribusiness, Faculty of Bioindustry, Universitas Trilogi, Indonesia.

E-Mail: arman@universitas-trilogi.ac.id

2. Asep Saefuddin, obtained his Doctoral degree from University of Guelph, Canada, in 1996. The author is a Professor at the Department of Statistics and Data Science, Faculty of Math and Science, IPB University, Indonesia.

E-Mail: asaefuddin@ipb.ac.id 